\title{
The Impact of General De la Rey's Death on the Political Situation in South Africa
}

\author{
WERONIKA MICHALSKA
}

\author{
University of Warsaw \\ Wydział Historii \\ Uniwersytet Warszawski \\ Krakowskie Przedmieście 26/ 28 \\ 00-927 Warszawa, Poland \\ wt.michalska@gmail.com
}

\begin{abstract}
The purpose of this article is to explain the historical significance of J.H. de la Rey's death by analyzing the general's political involvement at the beginning of the First World War. The author also examines the outbreak of the Boer Rebellion and De la Rey's attitude towards it. The controversies surrounding the night of September 15, 1914 are discussed after providing a detailed illustration of the events leading up to the shooting (the criminal activities of the Foster gang). It also analyzes the influence the general and Niklaas van Rensburg had on the Afrikaner society, which was faced with the option of revolting against the British. International media coverage of the accident is used in order to portray the world's reaction to the incident.
\end{abstract}

Keywords: J.H. de la Rey; 1914 Boer Rebellion; Foster gang; Niklaas van Rensburg

On September 15, 1914 in a village outside of Johannesburg called Langlaagte, a prominent Boer general, Jacobus (Koos) Herkulaas de la Rey was fatally shot by the police. This event is an important occurrence in Afrikaners' history because of the circumstances surrounding it. The tragedy had been prophesized by an influential seer, Niklaas van Rensburg. At the moment it became true, South Africa was in a difficult political situation. For these two reasons people had been conjuring conspiracy theories to explain the general's death. This incident shook the entire British Empire; foreign newspapers all over the world covered 
the investigation. In order to fully appreciate the importance of De la Rey's death it is necessary to consider the following: the position of the general in the Boer society, the circumstances surrounding the accident and the influence of the 'Seer' on the contemporary Afrikaners. The shooting of General De la Rey affected the political scene; without the famous Boer leading an armed protest, ${ }^{1}$ the Afrikaner society had to support either the government or the rebels.

The accident occurred during a police search for criminals known as the Foster gang. ${ }^{2}$ These men had committed three armed robberies and four murders since April of 1914 and on September 15, the police set up armed pickets along all major roads leaving Johannesburg in order to catch them (Gregorowski 1914: 1-3). The orders were to stop all cars leaving the city; the description of the fugitives' vehicle (black and four-seated) was given to every patrol. A similar car belonged to General Christiaan Beyers. That night it was driven by his chauffer, Wagner, ${ }^{3}$ who left Pretoria with General De la Rey and General Beyers in the backseat. As they drove through Johannesburg, the generals ignored the summons to stop at three pickets. The fourth checkpoint was located in Langlaagte and Constables Charles Drury and Charles Ives of the mounted police were there on duty. At around 9:15 PM Beyers' car neared the picket without losing speed and knocked Constable Drury over by striking his bayonet. Seeing no attempt to stop for the second officer, Drury fired at the back wheel. Unfortunately, he miscalculated the speed of the vehicle and the shot struck the ground, and ricocheted. The bullet hit De la Rey, sending a small piece of nickel into his heart, which killed him instantly (Gregorowski 1914: 7-10). All he said before he died was: "I've been hit, Chrisjaan" 4 (Orford 1971).

General De la Rey's death carried weight not only because of the surrounding circumstances but simply because a very highly respected man passed away. To the Afrikaners he was a brother ${ }^{5}$ or "Oom (Uncle) Koos;" he was also called "Lion of the Western Transvaal" (Swart 2004: 9), which is recognizable to this day. J. H. de la Rey was born in 1847 and at the age of nineteen gained his first military experience in the Basuto War of 1865 (Meintjes 1966: 36). He also fought against the British in 1880-81, but became famous during the Anglo-Boer War almost twenty years later. Even though De la Rey opposed declaring the war, he fully devoted himself to the cause once the Volksraad made its decision. He

\footnotetext{
${ }^{1}$ Wapen protest - an assembly of Boers with weapons, gathered to pressure the government into action.

${ }^{2}$ Foreign press called them the "Jackson gang."

${ }^{3}$ His first name does not appear in the sources.

4 "Dit is raak Chrisjaan."

${ }^{5}$ General De Wet's speech portrays it well: "I think of our deceased brother. We are used to saying 'burgher' or 'brother.' If there is someone here present who is not a brother, let him leave" (Swart 2004: 13).
} 
became a "Bittereinder" willing to fight "until they were utterly crushed in defeat or had won the battle and restored the republics' independence" (Giliomee 2003: 252). The Boers were defeated and De la Rey co-signed the Treaty of Vereeniging on May 31, 1902. Under British rule he continued to lead his people. Since 1907 he was a member of the Parliament for the Western Transvaal and when South Africa became a dominion, the "uncrowned king" (The Times 1915, 3: 500) represented his brethren in the Senate. He never lost his influence over the local community and the residents asked him what to think of the European conflicts in 1914 (Swart 2004: 13).

The British also held De la Rey in high regard because of the merciful treatment his prisoners received during the Anglo-Boer War. "The head of De la Rey's ambulance confessed that his orders always were to do everything that was possible for the English wounded, and that the general had a habit of visiting the prisoners himself to see that they were properly attended" (Examiner 1902: 13). An article applauding the conduct and personality of the Boer general was published in the Daily Mail and in the Australian Bathurst Press and Mining Journal. It was concluded with the following words: "General De la Rey is too good a soldier and has too high a respect for his opponents, to stoop to petty annoyances against the men who fall into his hands. He is in every sense of the term one of Nature's gentlemen - brave, courteous, and chivalrous" (Story 1901: 2). The author also believed that "in him is grand material for a loyal British subject" (Story 1901: 2). In fact, his enemy respected him so much in life that upon hearing of his death, King George V sent his condolences to the general's family (Clarence and Richmond Examiner 1914: 5). Andrew Fisher, the Australian Prime Minister, also wrote a special cable: "Regret the tragic death of General De la Rey, and sympathise with South Africa" (The Sydney Morning Herald 1914: 17). The sadness of the public is well portrayed by the titles published in New Zealand newspapers: "A Regrettable Occurrence. General De la Rey Shot by a Sentry" (Hawera \& Normanby Star 1914: 8) or "South Africa. A Sad Mistake. General De la Rey Shot Dead" (Ashburton Guardian 1914: 5). Most journalists only informed the public that the man was shot by the police; however, some articles also contain information on the Foster gang's suicide after being surrounded by the authorities on September $18{ }^{6}$ or on Beyers' resignation as the CommanderGeneral of the Union Defence Force (Traralgon Record 1914: 3). The leading British newspaper, The Times, reported on the events in South Africa in detail; for example, on October 2 it printed a summary of General Beyer's testimony (The Times Weekly Edition 1914: 772). The news of the shocking death also

\footnotetext{
6"The members of the Jackson [Foster] gang of criminals who were the real cause of the tragic death of General De la Rey [...] committed suicide"' (The Horsham Times 1914: 6).
} 
reached countries that were not part of the Empire - it was also reported in

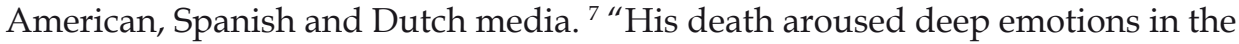
entire country" (Nieuwe Rotterdamsche Courant 1914: 2).

The funeral in Lichtenburg on September 20 was a reflection of De la Rey's position in the society. "[It] was attended by a large number of Boers, including the Prime Minister, General Smuts, General De Wet, and other Dutch generals. [...] A commando of 400 Burghers came from Wolmaranstad on horseback. English merchants from Johannesburg were also present [...]" (Plaatje 2007: 210). What is even more astonishing is that white inhabitants of South Africa were not the only ones that were touched by the man's death; "for the first time, the Dutch Reformed Church at Lichtenburg opened its doors to the blacks, who came to pay their last respects to, and view the body of, a popular Boer [...]" (Plaatje 2007: 210). Swart portrays De la Rey as a father-figure in the society; she claims that his say was worth so much and the Boers' loyalty so great that "in the early days of the Rebellion, in August, 'call up' was done verbally in the name of De la Rey" (Swart 2004: 9). "It is significant that the rank and file witnesses use names almost casually - their discussion of their part in the Rebellion are scanty, instead the names of leaders, the men themselves are given as the reason [for taking action]" 8 (Swart 2004: 12). "De la Rey's death had deprived them of the one man who could have raised the whole of the Western Transvaal against Botha" (The Times 1915: 501).

According to this, the people that lived in the Transvaal could not decide by themselves which side to choose and were waiting to see what De la Rey would do in order to blindly follow him. This was not the case. Swart writes that after he died, the phrase "De Wet is riding again!" (Swart 2004: 9) was enough to get some locals to rebel. The name of Izaak Claasen, a veldkornet (Swart 2004: 3) was the reason that a group of ex-commandos joined the revolt (Swart 2004: 2). Therefore, De la Rey was not the only influential person in the province and the Boers of the Transvaal that wished to rise against the government joined other leaders of the rebellion. Smith claims that Botha had a great number of supporters in that area, who did not wait to hear De la Rey's opinion before making up their minds (Smith 1976: 20). Though J.H. de la Rey unquestionably had great influence on the Afrikaners, he was not the only one. The result of the tragic September night was that Beyers lost a powerful partner who would lead the armed protest with him.

\footnotetext{
7 "Zuid-Afrika," Nieuwe Rotterdamsche Courant, Sept. 18, 1914, p. 2. “Noodlotige vergissing," Het Nieuws van den Dag voor Nederlandsche-Indië, Sept. 18, 1914, p. 3. "Desperadoes Self-Slain," New York Times, Sept. 18, 1914. "Muerte de un general boer" was published in several newspapers, for example in La Correspondencia de España: diario universal de noticias, Sept. 17 and 18, 1914 and in Diario de Tortosa on Oct. 2, 1914.

${ }^{8}$ Emphasis in the original.
} 
The unclear circumstances surrounding the shooting were used to recruit men to the rebels' camp. "At the funeral, speeches by Beyers and De Wet made Classen doubt that 'Oom Koos's' death was an accident, but rather part of a government plot" (Swart 2004: 13). He was not the only one with doubts.

Due to the uncertainties surrounding the events of September 15, a report was presented by The Hon. Mr. Justice Gregorowski who was the head of the Judicial Commission of Inquiry into the circumstances leading up to and attending upon the deaths of Senator General the Honourable J.H. De la Rey and Dr. G. Grace. During the seven-day hearing over seventy witnesses were questioned (Gregorowski 1914: 1). The purpose of the investigation was to determine what exactly had happened; whether or not the policemen had been justified in firing their weapons; and who was responsible for their actions. The value of this source lies in the witnesses' testimonies because they are unaltered. Also, the Foster gang that was indirectly responsible for the death of two innocent people is described in great detail. The report managed to identify the events that lead to the shooting of General De la Rey.

The inquiry does not seem to be influenced by the political situation in the country. It proved that Pretoria was in no way connected to what happened in Johannesburg that evening. It was known from the beginning that Constable Drury fired the shot that killed De la Rey; however, in order to convince people that the government did not conspire to murder the general, the commission followed and presented the chain of command. It also stated that:

There was also no opportunity of communicating with the police authorities in Pretoria and to take instructions there, and as a fact, no instructions were given from Pretoria, so that no responsibility attaches to Pretoria in connection with the tragic events which subsequently transpired. Whatever blame there may be, if any, rests upon the police authorities of the Witwatersrand. It may be mentioned that the only instructions emanating from Pretoria were given on the $13^{\text {th }}$ of September $[\ldots]$ that the constables on night duty in the Witwatersrand were to be armed with revolvers and ammunition. (Gregorowski 1914: 4)

This statement proves that the belief in a conspiracy theory was so strong that it had to be clearly disproved in the official report. A few pages later, the commission assures the public that "there is absolutely no foundation for the suggestion that a circuitous and out-of-the-way route was purposely taken by General Beyers in order to avoid the police or for any other purpose" (Gregorowski 1914: 8). This proves that the investigators wanted the people to stop drawing connections between the shooting and political situation. After the inquiry concluded the hearings, foreign newspapers announced its findings: De la Rey's death was an accident. 
An important question one must ask is whether the uncertainness surrounding the accident had an impact on the progress of the political situation. In the early days of World War I, the loyalty of South Africa to Great Britain was put to a test. Many Afrikaners still resented the British and were not willing to support their conquerors in the new conflict, especially not against Germany, which has sympathized with them at the turn of the century.

In certain districts [the war] revived ideas which had for long been sown in South African soil from German sources, official or unofficial, to the effect that when the day came for the downfall of the British Empire at the hand of Germany, it was the plan of the victors, not to annex the Transvaal and Orange Free State, but to constitute a new South African Republic under German protection. (The Round Table 1915: 220)

Though the Germans were unrightfully credited with planting ideas for independence in the minds of the Boers, the British correctly observed that the dream of sovereignty had not dwindled in the twelve years following the Treaty of Vereeniging. To some Boers, this was the opportunity to defy the British monarchy. This is why the Cabinet's (and later the Parliament's) agreement to lead an invasion of German South West Africa did not have total support of the population (Giliomee 2003: 380-81). In October, Lieutenant-Colonel Maritz revolted on the border between the Cape and the neighboring German colony, which marked the beginning of the Boer Rebellion of 1914 (Davenport 1963: 74). The authors of the The Times History of the War, published in twenty-two volumes between 1914 and 1921, believed that "with De la Rey dead, the plot drifted into a disorganization that made failure almost certain" (The Times 1915: 501). Davenport's opinion is that "[the coup d'état] failed for two main reasons: the shooting of De la Rey and the failure of Maritz to make the necessary arrangements in time" (Davenport 1963: 78). The most important aspect to consider is the purpose of the trip. The sources agree upon the destination - Potchefstroom and then Lichtenburg. The first place was a military base where 1,600 members of the Active Citizen Force were training. In charge of the camp was Major Jan Kemp, a man that will soon become one of the top leaders of the rebellion (Fouché 1915: 18). It is not possible to declare without a doubt what plans the generals had in mind when they would appear before the soldiers. We only have testimonies of the rebels, which are believed by some, but not by others. The most valuable one is of course that of General Beyers because he was the last one to speak with De la Rey. The general swore that they were not planning an insurrection (The Times 1915: 501).

Due to Beyers' role in the rebellion, the British did not believe his assurances, "at De la Rey's funeral, with a Bible in his hand, he passionately declared that rebellion was far from his thoughts and called the spirit of De la Rey to witness 
to the truth of this pitiful lie" (The Times 1915: 501). Report on the Outbreak of the Rebellion and the Policy of the Government with Regard to its Suppression (Fouché Report) said that the uprising was scheduled to begin in Potchefstroom at 4 AM on September 16 (Fouché 1915: 19). This document was created for the British government while the rebels were on trial for treason. Due to the timing of the publication of the report, the author was not allowed to identify his sources from which he collected evidence (Fouché 1915: 3). The value of the Fouché Report is the presentation of direct causes of the revolt. It is nevertheless limited to viewing the rebellion as a threat to British rule. The belief that the sole purpose was to overthrow the pro-British government and restore the Boer republics resulted in "a forthright condemnation of the rebel leaders" (Fouché 1915: 3). This is why British sources labeled Beyers as a conspirator from the beginning; "There is no doubt that when his car was summoned to stop outside Johannesburg he thought that he was trapped" (The Times 1915: 501), "he believed that the police were after him, that his plot had been discovered!" (Fouché1915: 18). Putting aside Beyers' alleged intentions and testimony, the behavior of De la Rey disproves the hypothesis that he was driving to Potchefstroom to start a rebellion.

General De la Rey did not support the idea of an offensive war against South West Africa (Meintjes 1964: 360); however, at a gathering on August 15, he convinced the assembled men to wait for the decision of the government, because they would surely do what was in the country's best interest (Fouché 1915: 8). The Fouché report declared: "the address seemed to have had a very good effect. The burghers appeared to have taken their leader's advice to heart, as they dispersed quietly to their homes. All danger of a rebellious movement had apparently been averted" (Fouché 1915: 8). At the Parliament session on September 15, De la Rey supported the decision to declare war on Germany (Giliomee 2003: 381); nevertheless, he was still convinced that a protest was necessary (Smith 1976: 15). The situation that South Africa found itself in depressed him greatly: "the future was so dark for him that he had said to God: Lord, take me, but think of the People and show them the good road" (J.E. de la Rey to J.C. Smuts, Nov. 9, 1914, in Hancock and Van Der Poel 1966: 606). In the end, "he was not prepared to use force or advise bloodshed. A 'wapen protes' was as far as he was prepared to go [...]" (Orford 1971). De la Rey was driving to Potchefstroom in order to relate the government's decision to the soldiers and officers in the camp (Smith 1976: 21). He was planning to be home on September 16, so he could not have hoped to lead a rebellion or even an armed protest (Smith 1976: 20-21). The importance of these circumstances is not easy to assess. It is possible, though, that by concentrating his own supporters on an armed protest, the rebels' forces would have been less numerous and therefore the rebellion could have occurred on a smaller scale. 
Niklaas van Rensburg, usually simply called 'Siener' ('Seer'), had an important role to play in convincing men to take up arms against the pro-British government. The Fouché report saw him as one of the main conspirators of the rebellion. The New York Times published a review of this document and concentrated on the 'Siener' because "he runs through the Government report like a scarlet thread through grey homespun" (New York Times 1915). Van Rensburg was in fact a very influential Boer. He foresaw many battles and concentration camps during the Anglo-Boer War (Orford 1971). Due to the religious symbolism and accuracy of his visions he was thought to be a prophet (Fouché 1915: 6). He was also a close friend of De la Rey (Orford 1971). 'Siener' saw his most famous vision in the company of Oom Koos and his daughter, Polly: the number 15 on a dark bleeding cloud, the general returning to Lichtenburg without a hat, a carriage with flowers, and a yellow box sent there by the Government (Orford 1971). "Both [Polly] and her father accepted that the vision of the General, without his hat, implied that he would be dead, for this was the 'Siener's' usual interpretation of such events. General de la Rey was to die on September 15, 1914, and incidentally 1914 also adds up to 15" (Orford 1971). However, a more optimistic interpretation became more widely believed. On the $15^{\text {th }}$ of an unspecified month, the Afrikaners will rise up to gain their independence. General De la Rey will succeed in restoring the Boer republics because Botha's government will secretly finance him (Orford 1971). It was also said that no blood would be shed (Fouché 1915: 8). God was believed to be on their side - after all, the prophet's visions came from the Lord (Giliomee 2003: 381). Even The Times History of War realized the religious aspect of the situation. Relating the accident, it stated, "there intervened a tragedy so fortuitous that they might well have seen in it the hand of Providence raised against them" (The Times 1915: 500). In fact, they did. Major Kemp in Potchefstroom "looked upon the event as a sign of divine disapproval of the proposed rising, and tried to withdraw his resignation" (Davenport 1963: 85). The major no longer wanted to leave the army, but his resignation had already gone through. Therefore, on September 21, Kemp attended a meeting in Lichtenburg along with generals Beyers and De Wet, and several hundred Boers. ${ }^{9}$ The gathering began with a prayer: "We thank Thee for such a man as General Beyers [...], General de Wet and General Kemp, and that Thou hast given us such men to lead us. We stand for our people. Help us, O Lord, towards the salvation of our people and the salvation of our fatherland. Amen" (Plaatje 2007: 210-211). References to God continued during the rebellion, "in the capital of South Africa, we shall, if God (in whom all our trust is) so wills, haul down the flag and proclaim our

\footnotetext{
${ }^{9}$ In Native Life in South Africa Plaatje wrote that 800-1000 people attended (Plaatje 2007: 210); the Fou-
} ché Report said there were 700-800 people (Fouché 1915: 21). 
independence" (De Wet letter, Nov. 5, 1914, in Fouché 1915: 32). “The seer Van Rensburg, who was always full of religious talk, had in this way acquired a considerable amount of influence over General De la Rey" (Fouché 1915: 17). Thus, it is understandable why 'Siener' held a high position in this Calvinistic society and why he did not lose it after his friend was shot. The Fouché report states "in the seer Van Rensburg the leaders possessed a most useful instrument for the work of deluding the simple-minded farmers and leading them almost unconsciously into rebellion" (Fouché 1915: 32). He supported the cause and the rebels held a meeting in his house on October 27 (Fouché 1915: 36). The shooting of De la Rey made his talent even more authentic in the eyes of the Afrikaners. This in turn, might have resulted in a stronger belief that the uprising would be bloodless and persuade people of the rightfulness of the fight for independence.

The tragic death of J.H. De la Rey in Langlaagte on September 15, 1914 had an impact on the course of the political history of the Union of South Africa. The popularity of the Boer while he was alive, the ambiguous circumstances of the accident, and the prophesies of Niklaas van Rensburg made his death an important event. Even though the general did not support Maritz' Rebellion, "the rebellion added the [name] of De la Rey [...] to their roll of honor. [He] had some title to be there already, but the uncertainties surrounding his death assured him of a special place" (Davenport 1963: 93). In reality, De la Rey called for an armed protest in order to prevent bloodshed and yet remind the government that the Afrikaners still dreamt of independence.

\section{Bibliography}

“A Regrettable Occurrence: General De la Rey Shot by a Sentry." Hawera \& Normanby Star. 17 Sept. 1914: 8.

"Boer Seer a Factor in the War." New York Times. 18 Apr. 1915.

"De la Rey." Nieuwe Rotterdamsche Courant. 17 Sept. 1914: 2.

"Desperadoes Self-Slain." New York Times. 18 Sept. 1914.

"General De la Rey Shot." Traralgon Record. 18 Sept. 1914: 3.

“General De la Rey." Examiner. 19 Apr. 1902: 13.

“General De la Rey." The Sydney Morning Herald. 19 Sept. 1914: 17.

“General De la Rey's Fate: Assassins Commit Suicide." The Horsham Times. 22 Sept. 1914: 6.

"Late General De la Rey." Clarence and Richmond Examiner. 22 Sept. 1914: 15.

"Muerte de un general boer." Diario de Tortosa. 2 Oct. 1914: 1.

"Muerte de un general boer." La Correspondencia de España: diario universal de noticias. 17 Sept. 1914: 7.

“Noodlotige vergissing." Het Nieuws van den Dag voor Nederlandsche-Indië. 18 Sept. 1914: 3.

"South Africa: A Sad Mistake. General De la Rey Shot Dead." Ashburton Guardian. 17 Sept. 1914: 5. 
“The Death of General De la Rey." The Times Weekly Edition. 2 Oct. 1914: 772.

"Zuid-Afrika." Nieuwe Rotterdamsche Courant. 18 Sept. 1914: 2.

Davenport, T.R.H. 1963. "The South African Rebellion 1914." The English Historical Review. Jan. 1963. Vol. 78. No. 306. Oxford: Oxford University Press. 73-94.

Giliomee, Hermann. 2003. The Afrikaners: Biography of a People. London: C. Hurst \& Co.

W.K. Hancock, and J. van Der Poel, eds. 1966. Selections from the Smuts Papers, Vol. 3. Cambridge: Cambridge University Papers.

Meintjes, Johannes. 1964. De La Rey - Lion of the West. Johannesburg: H. Keartland Publishers.

Orford, J.G. 1971. "The Verdict of History, Reflections on the possible influence of 'Siener' van Rensburg's visions on General J.H. 'Koos' de la Rey and some of the results." Military History Journal. 1 October 2013. <http:// samilitaryhistory.org/ vol022jo.html>.

Plaatje, Solomon T. 2007. Native Life in South Africa. Teddington: The Echo Library. <http://www.gutenberg.org/ebooks/1452>.

The Round Table. A Quarterly Review of the Politics of the British Empire. Vol. 5. 1914. London: Macmillan.

Smith, J.P. 1976. “Die Dood van Generaal De la Rey.” Scientia Militaria 6 (3): 6-23. <http://scientiamilitaria.journals.ac.za/pub/issue/view/129>.

Story, Douglas. 1901. "General De la Rey. In praise of a chivalrous soldier." Bathurst Free Press and Mining Journal. 26 Jan. 1901: 2.

Swart, Sandra. 2004. "'Men of Influence' - The Ontology of Leadership in the 1914 Boer Rebellion." Journal of Historical Sociology 17 (1). Oxford: Blackwell Publishing Ltd. 1-30.

The Times. 1915. The Times: History of the War. Vol. 3. London: "The Times" Printing House.

Union of South Africa. 1915. Report on the Outbreak of the Rebellion and the Policy of the Government with Regard to its Suppression. London: Darling and Son, Ltd.

Union of South Africa. Judicial Commission of Inquiry into the circumstances leading up to and attending upon the deaths of Senator General the Honourable J.H. De la Rey and Dr. G. Grace. 1914. Report of the Commissioner, the Hon. Mr. Justice Gregorowski. Cape Town: Cape Times Limited, Government Printers. 